\title{
Genetic and neuroinflammatory components of familial and sporadic cerebral Small Vessel Disease
}

Citation for published version (APA):

Koizumi, T. (2019). Genetic and neuroinflammatory components of familial and sporadic cerebral Small Vessel Disease. [Doctoral Thesis, Maastricht University]. Maastricht University. https://doi.org/10.26481/dis.20190828tk

Document status and date:

Published: 01/01/2019

DOI:

10.26481/dis.20190828tk

Document Version:

Publisher's PDF, also known as Version of record

\section{Please check the document version of this publication:}

- A submitted manuscript is the version of the article upon submission and before peer-review. There can be important differences between the submitted version and the official published version of record.

People interested in the research are advised to contact the author for the final version of the publication, or visit the DOI to the publisher's website.

- The final author version and the galley proof are versions of the publication after peer review.

- The final published version features the final layout of the paper including the volume, issue and page numbers.

Link to publication

\footnotetext{
General rights rights.

- You may freely distribute the URL identifying the publication in the public portal. please follow below link for the End User Agreement:

www.umlib.nl/taverne-license

Take down policy

If you believe that this document breaches copyright please contact us at:

repository@maastrichtuniversity.nl

providing details and we will investigate your claim.
}

Copyright and moral rights for the publications made accessible in the public portal are retained by the authors and/or other copyright owners and it is a condition of accessing publications that users recognise and abide by the legal requirements associated with these

- Users may download and print one copy of any publication from the public portal for the purpose of private study or research.

- You may not further distribute the material or use it for any profit-making activity or commercial gain

If the publication is distributed under the terms of Article $25 \mathrm{fa}$ of the Dutch Copyright Act, indicated by the "Taverne" license above, 


\section{Summary / Samenvatting}




\section{Summary}

cSVD is the most prevalent cause of vascular dementia which is itself the second most prevalent form of dementia after Alzheimer's Disease. Many studies have investigated the pathophysiological mechanisms of cSVD from a cerebrovascular point of view by focusing on endothelial cells, smooth muscle cells, extracellular matrix, and astrocytes. The aim of this thesis was to assess the genetic and neuroinflammatory components of cerebral small vessel disease (cSVD) (Chapter 1).

\section{Genetic contribution to cSVD}

cSVD can be either hereditary or sporadic, implying that an accurate diagnosis is required to distinguish both forms. Genetic testing is an important tool that does not allow however the screening of large number of patients for economic reasons. In chapter 2, we elaborated the CADASIL scale-J as an effective tool to access the genetic test for CADASIL-suspected patients with high sensitivity and specificity. This scale allows to set priorities for the genetic testing of suspected patients and to avoid unnecessary testing for patients not at risk. While setting up this scale, the comparison of similar populations of CADASIL and nonNOTCH3 patients, led us to reconfirm hypertension and diabetes as crucial factors in the characterization of sporadic cSVD (Chapter 2).

\section{Neuroinflammatory contribution to cSVD}

Neuroinflammation has gained importance in the mechanistic hypothesis of cSVD development. In this thesis, we focused on the involvement of CNS immune cells - microglia and perivascular macrophages - during cSVD. In particular, we have differentiated perivascular microglia from parenchymal microglia in our studies to gain more insights into the potential specific roles of vascular-associated immune cells. We initiated experimental studies to analyze the dynamics of CNS immune cells in hypertensive- and/or diabetes-induced cSVD. First of all, to understand the differential roles of perivascular microglia and perivascular macrophages, we reviewed the literature associated with those cells and their involvement in neurological diseases. We explored the knowledge regarding their ontogeny, their expression of surface markers, and their involvement in neurological diseases (Chapter 3). In our first experimental study with a hypertensive rat model, we observed that the phenotype of perivascular microglia was changed with the progression of hypertension. Importantly, perivascular microglia were proliferating prior to the occurrence of cerebrovascular lesions and associated signs without harboring a proinflammatory (M1-state) or anti-inflammatory (M2-state) phenotype. This was followed by a pro-inflammatory state with no transition by the anti-inflammatory 
phenotype. Once the cerebrovascular lesions were visible, non-proliferative M1state microglia were massively present (Chapter 4).

While studies focused on the single contribution of hypertension and type 2 diabetes respectively have been performed to elucidate their contribution towards neuroinflammation, their combined effect remains understudied. In chapter 5, we describe the dynamics of CNS immune cells during hypertension and/or type 2 diabetes by using ZSF-1 rats. Type 2 diabetes did accelerate the M1-state activation of perivascular microglia earlier than for parenchymal microglia, while perivascular macrophages were always highly activated towards an anti-inflammatory M2-state or a pro-inflammatory M1-state (Chapter 5).

Finally, chapter 6 includes a general discussion and a summary of the main findings obtained in this thesis (Chapter 6). In summary, we established the CADASIL scale-J to prioritize the genetic testing for CADASIL-suspected patients. In experimental sporadic cSVD models, we identified that perivascular microglia were dynamically activated during cSVD formation and that their activation dynamics can be influenced by the combination of vascular risk factors. This activation dynamics differed from perivascular macrophages, highlighting the need to study the function of the different perivascular immune cell populations.

\section{Nederlandse Samenvatting}

cSVD is de meest voorkomende oorzaak van vasculaire dementie en daarnaast de tweede meest voorkomende vorm van dementie na de Ziekte van Alzheimer. Vele studies hebben onderzoek gedaan naar de pathofysiologische mechanismen van cSVD vanuit een cerebrovasculaire standpunt door te focussen op de endotheliale cellen, gladde spiercellen, extracellulaire matrix en astrocyten. Het doel van deze proefschrift was een beter inzicht te geven in de genetische en neuro-inflammatoire componenten van cerebral small vessel disease (cSVD) (Hoofdstuk 1).

\section{Genetische bijdrage aan cSVD}

cSVD kennen zowel een erfelijke als een sporadische oorsprong. Hetgeen impliceert dat een accurate diagnose vereist is om beide vormen te onderscheiden. Genetisch testen is een belangrijke tool, echter om economische redenen is screening van een groot aantal patiënten niet doenlijk. In hoofdstuk 2, hebben wij de CADASIL schaal-J uitgewerkt als een doeltreffend instrument om 
toegang te krijgen tot de genetische test voor CADASIL-verdachte patiënten met hoge gevoeligheid en specificiteit. Met behulp van deze schaal kunnen prioriteiten voor de genetische tests van verdachte patiënten worden gesteld om daarmee te voorkomen dat onnodige proeven voor patiënten worden doorgevoerd. Tijdens het opzetten van deze schaal, m.n. de vergelijking van soortgelijke populaties van CADASIL en niet-NOTCH3 patiënten, werd duidelijk dat hypertensie en diabetes als cruciale factoren gezien kunnen worden in de karakterisering van sporadische cSVD (hoofdstuk 2).

\section{Neuroinflammatoire bijdrage aan cSVD}

Neuroinflammatie is van belang in de mechanistische hypothese van cSVD ontwikkeling. In dit proefschrift hebben we onze aandacht gericht op de betrokkenheid van de CNS immuun cellen, microglia en gerelateerde macrofagen tijdens cSVD. We hebben getracht in het bijzonder gerelateerde microglia te onderscheiden van parenchymale microglia om daarmee meer inzicht te verkrijgen in de potentiële specifieke rollen van vasculairegeassocieerde immuun cellen. Wij zijn begonnen met experimentele studies voor het analyseren van de dynamiek van de CNS immuun cellen in Hypertensieve en/of diabetes-geïnduceerde cSVD. Eerst en vooral, om meer inzicht te krijgen in de differentiële rollen van gerelateerde microglia en gerelateerde macrofagen, hebben we de literatuur bestudeerd die de betrokkenheid aangaf van deze cellen bij verschillende neurologische ziekten. We hebben in ons review samengevat de kennis over hun ontogenie, hun uitdrukking van oppervlakte markers en hun betrokkenheid bij neurologische aandoeningen (hoofdstuk 3 ).

In onze eerste experimentele studie met een hypertensief rat model hebben we vastgesteld dat het fenotype van gerelateerde microglia veranderd naarmate er is een progressie van hypertensie. Bovendien, gerelateerde microglia waren prolifererend voorafgaand aan het optreden van cerebrovasculaire laesies en bijbehorende tekenen zoals een pro-inflammatoire (M1-state) of antiinflammatoire (M2-state) fenotype. Dit werd gevolgd door een proinflammatoire status zonder transitie door het anti-inflammatoire fenotype. Zodra de cerebrovasculaire letsels zichtbaar waren, bleken ook nietproliferatieve M1 statuswaarden microglia massaal aanwezig te zijn (Hoofdstuk 4).

Hoewel onze studies op de bijdrage van hypertensie en diabetes type 2 respectievelijk gericht waren, hebben we onderzoek verricht om een beter beeld te krijgen in hun bijdrage aan de neuroinflammatie. Hun gecombineerde effect blijft niet goed onderzocht. In hoofdstuk 5, hebben we beschreven de dynamiek van de CNS immuun cellen tijdens hypertensie en/of diabetes type 2 met behulp van ZSF-1 transgene ratten. Diabetes type 2 versnelt de M1-state activering van 
gerelateerde microglia eerder dan voor parenchymale microglia, terwijl gerelateerde macrofagen altijd zeer geactiveerd werden naar een antiinflammatoire M2-status of een pro-inflammatoire M1-status (Hoofdstuk 5).

Hoofdstuk 6 bevat ten slotte een oriënterend discussie en een samenvatting van de belangrijkste bevindingen in mijn proefschrift. Resumerend, met de CADASIL schaal-J kunnen we een prioriteit stellen bij het genetische testen voor CADASIL verdachte patiënten. In experimentele sporadische cSVD modellen, hebben we vastgesteld dat gerelateerde microglia dynamisch waren geactiveerd tijdens de vorming van de cSVD en dat hun dynamiek van activering kan worden beïnvloed door de combinatie van vasculaire risicofactoren. Deze dynamiek van activering verschilt van gerelateerde macrofagen, daarbij kan worden gewezen op de noodzaak de functie van de verschillende gerelateerde immuun cel populaties te bestuderen.

\section{Samenvatting}

Het doel van dit proefschrift was om de genetische, m.n. de neuro-inflammatoire mechanismen of van cerebrale Small Vessel Diseases (cSVD) te bestuderen. De cSVD is de belangrijkste oorzaak van vasculaire dementia, de op een na meest voorkomende vorm van dementia. 